\title{
2019 Novel Coronavirus in the light of current knowledges: Facts and unknowns
}

\section{Güincel billgiler’ ışığında 2019 yeni Koronavirǚs: Gerçekler ve bilinmeyenler}

\author{
Aynur Engin
}

Enfeksiyon Hastalıkları Anabilim Dalı, Sivas Cumhuriyet Üniversitesi Uygulama ve Araștırma Hastanesi, Sivas, Türkiye

Corresponding author: Aynur Engin, MD., Enfeksiyon Hastalıkları Anabilim Dalı, Sivas Cumhuriyet Üniversitesi Uygulama ve Araştırma Hastanesi, Sivas, Türkiye

E-mail: aynurum2000@yahoo.com

Received/Accepted: April 07,2020/April 07,2020

Conflict of interest: There is not a conflict of interest.

\begin{abstract}
SUMMARY
On 31 December 2019, a cluster of pneumonia cases of unknown aetiology was reported in Wuhan, Hubei Province, China. Soon afterwards, China's scientists have defined a new coronavirus as the essential causative agent. The outbreak has quickly developed affecting other parts of China and outside the country. At the early period of outbreak the new virus called as 2019-nCoV. On February 12, 2020, the novel coronavirus has been renamed severe acute respiratory syndrome coronavirus 2 (SARS-CoV-2). The official name for the disease causing the 2019 novel coronavirus outbreak is now referred to as COVID-19. Cases have now been determined in a lot of countries in Asia, but also in Australia, Europe, North America, and Africa. A total of 78 811cases of COVID-19 infection were notified up until 23 February 2020 in the world. As of February 23, 2020, 77042 confirmed cases and 2445 deaths have been reported in China. The clinical view of 2019-nCoV infection ranges from asymptomatic infection to severe pneumonia with acute respiratory distress syndrome, septic shock and multi-organ failure, that can outcome in death. There is no specific antiviral drug for treatment and an approved vaccine for COVID-19 yet.
\end{abstract}

Keywords: 2019 novel CoV, COVID-19, SARS-CoV-2, Wuhan
(iD) Aynur Engin

ORCID IDs of the authors:

A.E. 0000-0002-8533-8793

ÖZET

31 Aralık 2019 tarihinde Çin'in Hubei eyaletindeki Wuhan şehrinde, nedeni bilinmeyen pnömoni vakalarında bir kümelenme saptandı. Kısa bir süre sonra Çin bilim adamları, bu olgulardaki etkenin yeni bir koronovirüs olduğunu saptadılar. Yeni virüs ile ortaya çıkan salgın hızla Çin'in diğer bölgelerini ve Çin dışındaki ülkeleri etkiledi. Salgının ilk döneminde bu yeni virüs 2019-nCoV olarak adlandırıldı. 12 Subat 2020'de ise virüs, ciddi akut solunum sendromu koronavirüs 2 (SARS-CoV-2) olarak yeniden adlandırıldı. 2019 yeni korona virüsünün neden olduğu hastalığa da resmi ad olarak COVID-19 adı verildi. Olgular Asya kıtasındaki çeşitli ülkelerin yanı sıra Avustralya, Avrupa, Kuzey Amerika ve Afrika kıtalarında da saptand1. 23 Şubat 2020 tarihi itibarı ile, dünyada toplam 78811 COVID-19 enfeksiyonu bildirildi. 23 Șubat 2020 itibariyle, Çin'de 77042 doğrulanmıș vaka ve 2445 ölüm bildirildi. 2019-nCoV enfeksiyonunun klinik seyri, asemptomatik enfeksiyondan ölümle sonlanabilen çoklu organ yetmezliği, septik şok ve akut solunum sıkıntısı sendromunun eşlik ettiği ciddi pnömoniye kadar değişken olabilir. COVID-19 tedavisi için onaylanmış spesifik antiviral bir ilaç yada așı henüz bulunmamaktadır.

Anahtar sözcükler: 2019 yeni koronavirus, COVID-19, SARS-CoV-2, Wuhan 


\section{INTRODUCTION}

In Wuhan, China a novel and alarmingly contagious primary atypical pneumonia broke out in December 2019. Soon after the causative agent was identified as a novel coronavirus by China's health authorities ${ }^{1}$. A novel coronavirus $(\mathrm{CoV})$ is a new strain of coronavirus that has not been priorly described in humans. At the early period of outbreak the new virus provisionally named 2019$\mathrm{nCoV}$. The new virus quickly infected thousands of people, especially in China. The clinical view of 2019-nCoV infection ranges from asymptomatic infection to severe pneumonia with acute respiratory distress syndrome, septic shock and multi-organ failure, that can outcome in death.

The rapid spread of the disease caused panic of the people. There was produced some conspiracy theories about the new virus. Some misinformation has spread rapidly on the internet among the public. For example, in the early period of outbreak, one paper wrongly claimed that amino acid residues in the 4 inserts in the spike glycoprotein which are unique to the 2019-nCoV have similarity to those in the HIV-1 gp120 or HIV-1 Gag. These claims have resulted in considerable public panic and controversy in the community. Biologists rapidly denied this, emphasizing that the supposed similarities are present in lots of viruses. Soon after, the authors withdrew the approval of nowdiscredited study that linked coronavirus to HIV ${ }^{2}$.

In this article, it is reviewed the epidemiology, virologic and clinical features, diagnosis, management, and prevention of 2019-nCoV infection in the light of current knowledges.

\section{VIROLOGY}

Coronaviruses are a family of viruses that infect a wide range of several species including humans, cattle, pigs, chickens, dogs, cats and wild animals. Coronaviruses are enveloped positive-stranded RNA viruses whose name derives from their characteristic crown-like appearance in electron micrographs ${ }^{3}$. Schematic structure of Coronavirus is shown Figure $1^{4}$.

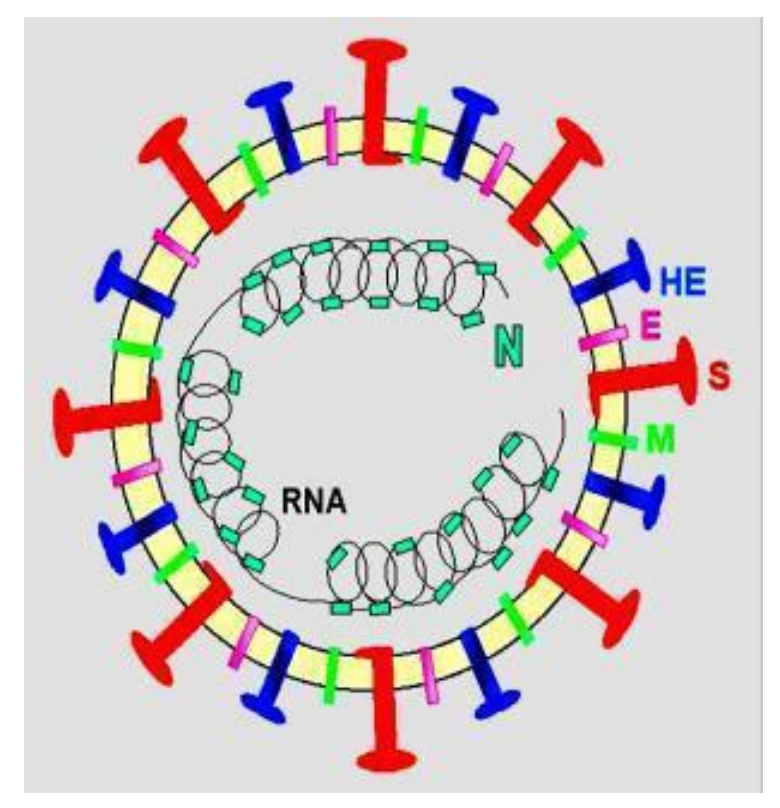

Figure 1: A schematic structure of Coronavirus ${ }^{4}$

Footnotes: S: spike protein; M: membrane protein; E: envelope protein; N: nucleocapsid protein.

The coronavirus subfamily is further classified into four genera as alpha, beta, gamma, and delta coronaviruses. Human coronaviruses (HCoVs) were first described in the 1960s for patients with the common cold ${ }^{5}$. The human coronaviruses are in two of these genera: alpha coronaviruses (HCoV-229E and HCoV-NL63) and beta coronaviruses (HCoV-HKU1, HCoV-OC43, MERS-CoV, and SARS-CoV). Four of HCoVs
(HCoV 229E, NL63, OC43, and HKU1) are endemic globally and account for $10 \%$ to $30 \%$ of upper respiratory tract infections in adults ${ }^{6}$. Until 2002, HCoVs generally has caused mild respiratory illnesses. However since 2002 two new coronaviruses (severe acute respiratory syndrome (SARS) and Middle East respiratory syndrome (MERS) coronaviruses) has been diagnosed. SARS and MERS CoVs has infected people and caused 
severe disease. And finally, on December 2019, a new virus, $2019 \mathrm{nCoV}$, has been added, emerging from Wuhan. The new coronavirus from Wuhan is one that has never been seen before this epidemic. The knowledge of us about this new virus is not enough yet. However, research of the genome sequence demonstrates strong homology with SARS-CoV.

The coronavirus genome codes four or five structural proteins. These are S, M, N, HE, and E. The S, M, N, and E proteins code by HCoV-229E, HCoV-NL63, and the SARS coronavirus. However, HCoV-OC43 and HCoVHKU1 also include a fifth gene that codes the HE protein ${ }^{3}$. The spike (S) protein projects through the viral envelope and forms the characteristic spikes in the coronavirus "crown".

At the early period of outbreak the new virus called as 2019-nCoV. It was designation as 2019-nCoV, because, 2019 for year of detection, $\mathrm{n}$ for novel (meaning new) and CoV for coronavirus. However 2019-nCoV was not official name of the new virus. Moreover, some people call as Wuhan coronavirus to this new virüs. In the later period of the outbreak, on February 12, 2020, the novel coronavirus was renamed severe acute respiratory syndrome coronavirus 2 (SARS-CoV-2). The disease associated with the new virus is now called to as COVID-19. COVID-19 is a short for "coronavirus disease 2019".

The new name of the virus, SARS-CoV-2, was introduced recently, and at present, the former name is more known in public. Therefore, the former name of the virus, 2019-nCoV, was more common use in this article. Full-genome sequencing and phylogenic analysis indicated that $2019-\mathrm{nCoV}$ is a betacoronavirus in the same subgenus as SARS virus, but in a different clade. MERS virus, another betacoronavirus, was more distantly related. It was reported that 2019-nCoV might be able to bind to the angiotensin-converting enzyme 2 (ACE2) receptor in humans ${ }^{7}$. Wan et al., reported that the novel virus's receptor-binding motif that directly contacts ACE2, is similar to that of SARS-CoV ${ }^{8}$.

Coronovirus can be zoonotic origin. For example, it is known that SARS-CoV was transmitted to humans from civet cats and MERS-CoV is transmitted from camels to humans. 2019-nCoV has close similarity to bat coronaviruses. Thus, it is possible that bats are the primary source. However, whether 2019-nCoV is transmitted directly from bats or through some other mechanism (by an intermediate host) is unknown. During the 2019nCoV outbreak, different animals were suggested as a potential source or intermediate host for it. In a study by Liu et al, coronaviruses were detected as potential pathogens of Malayan pangolins. The authors reported that though there was high species variety of Coronavirus detected, SARS-CoV was the most widely distributed. Liu et al., suggested that Malayan pangolins could be a host with the potential of transmitting the SARS coronavirus to humans ${ }^{5}$. Interestingly, on 7 Feb, Shen Yongyi and Xiao Lihua who worked at the South China Agricultural University have described the pangolin as the potential source of $2019-\mathrm{nCoV}$ on the basis of a genetic comparison of coronaviruses received from the animals and from infected people. They reported at a press conference, genetic sequences of viruses separated from this animals are $99 \%$ similar to that of the circulating virus. But some scientists have thought that the research was far from robust and this is not scientific evidence. Because the evidence for the potential involvement of pangolins in the outbreak has not been formally published, other than by a university press release. Also some scientists in Beijing claimed that snakes were the origin of 2019-nCoV, but that theory was rejected by other researchers 9. After all, we still don't know, whether 2019-nCoV is transmitted directly from bats or by means of intermediate hosts.

\section{EPIDEMIOLOGY}

Up until now, there have been 3 major outbreaks with coronaviruses. These are SARS-CoV, MERS$\mathrm{CoV}$ and finally SARS-CoV-2 (formerly 2019$\mathrm{nCoV})$. The SARS outbreak, which also originated in China, killed 774 people worldwide. Globally 8096 SARS cases were reported (based on data as of the 31 December 2003). Case fatality ratio of SARS-CoV infection was $9.6 \%{ }^{10,11}$. Between 2012 and 30 June 2018, 2229 laboratory confirmed cases of MERS-CoV infection (one of them from Turkey) were reported to WHO, $83 \%$ of whom were reported by the Kingdom of Saudi Arabia. To date, 791 individuals have died (crude case fatality rate $35.5 \%$ ) due to MERS-CoV infection ${ }^{12}$. Finally, on 31 December 2019, a new coronavirus (2019-nCoV) has been reported from China ${ }^{1}$. In fact, $\mathrm{Li}$ et al., has reported that patients began to appear on the December 12, $2019^{13}$. On January 7, 2020, the Chinese scientists isolated the new type of coronavirus. And 5 days later, on Jan 12, 2020, China shared the genetic sequence of the novel coronavirus for countries to use in forming specific diagnostic kits ${ }^{1}$.

The initial source of 2019-nCoV still remains unknown. Initially, Chinese Health officials declared the outbreak originated at the Huanan 
Seafood Market. This theory is possible but not substantiated yet. In this market, there was outdoor stalls selling fish and meat, some of it from wildlife. The seafood market also sold live rabbits, snakes, and other animals. Some patients had worked or visited there. Thus, Huanan Seafood Market was blamed as most probable index source of zoonotic 2019-nCoV infections. The Huanan Seafood Wholesale Market in Wuhan city was closed by officials on Jan 1, 2020 for environmental sanitation and disinfection ${ }^{1}$. But, as the outbreak progressed, it was determined a lot of laboratory-confirmed cases had no contact with this market. Human-to-human transmission has been confirmed in China and the other countries.

We do not have enough knowledge about how 2019-nCoV spreads. Our existing knowledge is generally based on what is known about other coronaviruses ${ }^{14}$. Spread from person-to-person commonly occurs between close contacts (around 1 meter). Person-to-person spread is thought to occur largely via respiratory droplets. The droplets can be produced when an infected person coughs or sneezes. It is also possible that a person can take 2019-nCoV by touching a surface or object having the virus on it and then touching their own mouth, nose, or probably their eyes ${ }^{14}$. The WHO has reported that according to recent reports, the people with infected with 2019-nCoV can also be infectious during asymptomatic period ${ }^{15}$.

On 13 January 2020, the Ministry of Public Health, Thailand reported the first imported case of labconfirmed novel coronavirus (2019-nCoV) from Wuhan, China. On 15 January 2020, the Ministry of Health, Labour and Welfare, Japan reported an imported case of laboratory-confirmed 2019-novel coronavirus (2019-nCoV) from Wuhan, China. And then cases from different countries began to be reported. The number of cases increased steadily. On 23 January 2020, the first case of 2019-nCoV was reported in the United States. First confirmed case in Australia was reported on January 25, 2020. On January 27, 2020, first case reported in Canada. On 30 January 2020, the International Health Regulations Emergency Committee of the World Health Organization announced the outbreak a "public health emergency of international concern" 16. The first death has been reported outside of China, in the Philippines on 2 February 2020. The first case in the Europe were confirmed in France on January $25,2020^{17}$.
As of today (23 February 2020), WHO announced globally 78 811confirmed cases of COVID-19 ${ }^{18}$. Most of these cases (77 042) are in China and 2445 deaths was occured in China. And the case count has been rising daily. According to the report released by the WHO, there are 17 death cases reported outside China as of Feb 23, 2020; these are from Philippines (1), Japan (1), Italy (2), France (1), Iran (5), Republic of Korea (5) and other (Diamond Princess which is a cruise ship currently in Japanese territorial waters) (2). As of February 23, 2020, the situation reports of the World Health Organization and the number of confirmed COVID-2019 cases reported through these reports are shown in Table $1^{17}$. The map of countries, territories or areas with reported confirmed cases of COVID-19 is shown Figure ${ }^{18}$.

Although it is very close, the number of COVID19 cases are differ slightly between WHO and European Centre for Disease Prevention and Control (ECDC). According to the ECDC, countries, territories or areas with reported confirmed COVID-19 cases and deaths worldwide is shown in Table 2. In Table 2 is shown data as of 23 February $2020{ }^{19}$.

As of 23 February, 2020, 121 cases and three deaths have been reported in the EU/EEA and the UK (EU: European Union, EEA: European Economic Area and UK: the United Kingdom) ${ }^{20}$. Distribution of laboratory confirmed cases of COVID-19 in the EU/EEA and the UK, as of 23 February 2020 shows in Table 3.

As of 20 February 2020, Egypt is the first country to report a confirmed case from the African continent. At present, cases have been reported in 5 different continents (Asia, Europe, America, Australia, and Africa). As of 23 February 2020, the cases were reported from 28 countries in addition to China. There are also 634 cases identified on a cruise ship currently in Japanese territorial waters $^{18}$.

According to data reporting on 14 February 2020, Health care workers (HCWs) account for 1716 confirmed cases of COVID-19 including six deaths in China ${ }^{21}$. One of the deceased HCWs was Dr Li Wenliang. Doctor Li Wenliang, who was among the first triying to warn about the coronavirus outbreak in late December, died on 7 February 2020, after becoming infected with the new virus. Dr Li, an ophthalmologist in Wuhan, caught the virus from a infected patient ${ }^{22}$. 


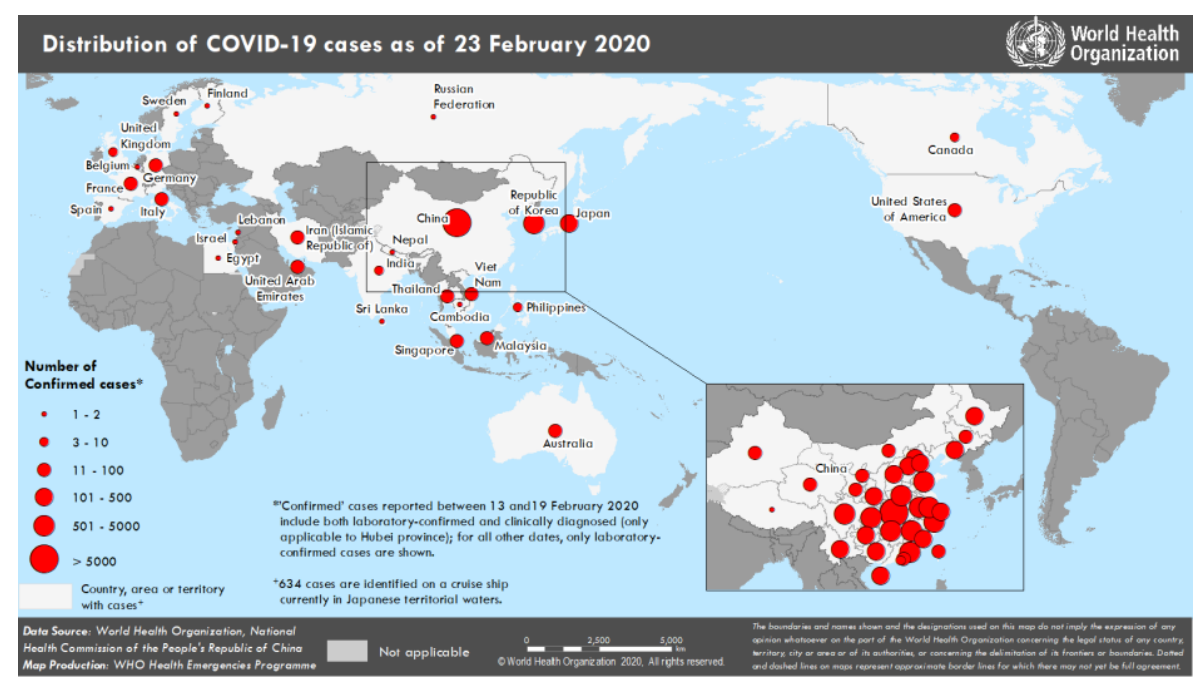

Figure 2: The map of countries, territories or areas with reported confirmed cases of COVID-19, 23 February $2020^{18}$.

Table 1: As of February 23, 2020, the situation reports of the World Health Organization (WHO) and the number of confirmed COVID-2019 cases reported through these reports ${ }^{17}$

\begin{tabular}{|c|c|c|c|c|c|c|}
\hline Raport no & $\begin{array}{l}\text { Date }^{\mathrm{a}} \\
(2020)\end{array}$ & Globally $^{\mathrm{b}}$ & China $^{\mathrm{c}, * *}$ & $\begin{array}{l}\text { Deaths } \\
\text { (in China) }\end{array}$ & $\begin{array}{l}\text { Outside of China } \\
\text { (total case number) }\end{array}$ & $\begin{array}{l}\text { Countries }^{\mathrm{d}} \\
\text { (number) }\end{array}$ \\
\hline 1 & 20 January & 282 & 278 & 6 & 4 & 3 \\
\hline 2 & $21 \mathrm{Jan}$ & 314 & $309^{*}$ & 6 & 4 & 3 \\
\hline 3 & 23 Jan & 581 & $571^{*}$ & 17 & 7 & 4 \\
\hline 4 & 24 Jan & 846 & $830 *$ & 25 & 11 & 6 \\
\hline 5 & 25 Jan & 1,320 & 1,297 & 41 & 23 & 9 \\
\hline 6 & $26 \mathrm{Jan}$ & 2,014 & 1,985 & 56 & 29 & 10 \\
\hline 7 & 27 Jan & 2798 & 2761 & 80 & 37 & 11 \\
\hline 8 & $28 \mathrm{Jan}$ & 4593 & 4537 & 106 & 56 & 14 \\
\hline 9 & 29 Jan & 6065 & 5997 & 132 & 68 & 15 \\
\hline 10 & $30 \mathrm{Jan}$ & 7818 & 7736 & 170 & 82 & 18 \\
\hline 11 & 31 Jan & 9826 & 9720 & 213 & 106 & 19 \\
\hline 12 & 1 February & 11953 & 11821 & 259 & 132 & 23 \\
\hline $13^{\mathrm{e}}$ & $2 \mathrm{Feb}$ & 14557 & 14411 & 304 & 146 & 23 \\
\hline 14 & $3 \mathrm{Feb}$ & 17391 & 17238 & 361 & 153 & 23 \\
\hline 15 & $4 \mathrm{Feb}$ & 20630 & 20471 & 425 & 159 & 23 \\
\hline 16 & $5 \mathrm{Feb}$ & 24554 & 24363 & 491 & 191 & 24 \\
\hline 17 & $6 \mathrm{Feb}$ & 28276 & 28060 & 564 & 216 & 24 \\
\hline 18 & $7 \mathrm{Feb}$ & 31481 & 31211 & 637 & 270 & 24 \\
\hline 19 & $8 \mathrm{Feb}$ & 34886 & 34598 & 723 & 288 & 24 \\
\hline 20 & $9 \mathrm{Feb}$ & 37558 & 37251 & 812 & 307 & 24 \\
\hline 21 & $10 \mathrm{Feb}$ & 40554 & 40235 & 909 & 319 & 24 \\
\hline 22 & $11 \mathrm{Feb}$ & 43103 & 42708 & 1017 & 395 & 24 \\
\hline 23 & $12 \mathrm{Feb}$ & 45171 & 44730 & 1114 & 441 & 24 \\
\hline 24 & $13 \mathrm{Feb}$ & 46997 & 46550 & 1368 & 447 & 24 \\
\hline $25^{\mathrm{f}}$ & $14 \mathrm{Feb}$ & 49053 & 48548 & 1381 & 505 & 24 \\
\hline 26 & $15 \mathrm{Feb}$ & 50580 & 50054 & 1524 & 526 & 25 \\
\hline $27^{g}$ & $16 \mathrm{Feb}$ & 51857 & 51174 & 1666 & 683 & 25 \\
\hline $28^{\mathrm{h}}$ & $17 \mathrm{Feb}$ & 71429 & 70635 & 1772 & 794 & 25 \\
\hline 29 & $18 \mathrm{Feb}$ & 73332 & 72528 & 1870 & 804 & 25 \\
\hline 30 & $19 \mathrm{Feb}$ & 75204 & 74280 & 2006 & 924 & 25 \\
\hline $31^{\mathrm{j}}$ & $20 \mathrm{Feb}$ & 75748 & 74675 & 2121 & 1073 & 26 \\
\hline 32 & $21 \mathrm{Feb}$ & 76769 & 75569 & 2239 & 1200 & 26 \\
\hline 33 & $22 \mathrm{Feb}$ & 77794 & 76392 & 2348 & 1402 & 28 \\
\hline 34 & $23 \mathrm{Feb}$ & 78811 & 77042 & 2445 & 1769 & 28 \\
\hline
\end{tabular}

a: The date is the date as data reported.

b: Total confirmed cases in the world.

c: Total confirmed cases in China. 
d: The number of countries outside of China.

e: In situation report 13, the first death has been reported outside of China, in the Philippines (1 case).

$\mathrm{f}$ : In situation report 25 , the second death has been reported outside of China, in Japan (1 case).

g: In situation report 27, a third death of a COVID-19 patient has been reported outside of China. This individual was a tourist from China visiting France.

h: WHO reported only laboratory-confirmed cases until 16 February 2020. However, from situation report 28 (17 February 2020), WHO is also reporting clinically diagnosed cases from Hubei province in addition to laboratory-confirmed cases as confirmed cases.

J: In situation report 31, it was reported 5 new death cases. One of them from Republic of Korea, 2 of them from Iran, and 2 of them from Diamond Princess which a cruise ship currently in Japanese territorial waters.

*The cases in Taipei Municipality, Hong Kong Special Administrative Region, and Macau Special Administrative Region are included in the globally cases.

** In the situation reports from 5 to 34, the cases in Taipei Municipality, Hong Kong Special Administrative Region, and Macau Special Administrative Region are included in the China cases.

Table 2: Countries, territories or areas with reported confirmed COVID-19 cases and deaths. Data as of 23 February $2020^{19}$

\begin{tabular}{|c|c|c|c|c|}
\hline Continent & Country / Territory / Area & $\begin{array}{l}\text { Confirmed } \\
\text { cases }\end{array}$ & Deaths & Comments \\
\hline Asia & & 78009 & 2458 & \\
\hline Asia & China & 77035 & 2445 & $\begin{array}{l}\text { Including } 64084 \text { cases } \\
\text { from Hubei povince }\end{array}$ \\
\hline Asia & Republic of Korea & 602 & 5 & \\
\hline Asia & Japan & 132 & 1 & \\
\hline Asia & singapore & 89 & 0 & \\
\hline Asia & Thailand & 35 & 0 & \\
\hline Asia & Iran (Islamic Republic of) & 28 & 5 & \\
\hline Asia & Taiwan & 26 & 1 & \\
\hline Asia & Malaysia & 22 & 0 & \\
\hline Asia & Vietnam & 16 & 0 & \\
\hline Asia & United Arab Emirates & 13 & 0 & \\
\hline Asia & Philippines & 3 & 1 & \\
\hline Asia & India & 3 & 0 & \\
\hline Asia & Cambodia & 1 & 0 & \\
\hline Asia & Lebanon & 1 & 0 & \\
\hline Asia & Israel & 1 & 0 & \\
\hline Asia & Nepal & 1 & 0 & \\
\hline Asia & Sri Lanka & 1 & 0 & \\
\hline Other & & 634 & 2 & \\
\hline Other & Cases on an international conveyance Japan & 634 & 2 & \\
\hline Europe & & 123 & 3 & \\
\hline Europe & Italy & 79 & 2 & \\
\hline Europe & Germany & 16 & 0 & \\
\hline Europe & France & 12 & 1 & \\
\hline Europe & United Kingdom & 9 & 0 & \\
\hline Europe & Spain & 2 & 0 & \\
\hline Europe & Russia & 2 & 0 & \\
\hline Europe & Sweden & 1 & 0 & \\
\hline Europe & Finland & 1 & 0 & \\
\hline Europe & Belgium & 1 & 0 & \\
\hline America & & 44 & 0 & \\
\hline America & United States of America & 35 & 0 & \\
\hline America & Canada & 9 & 0 & \\
\hline Oceania & & 22 & 0 & \\
\hline Oceania & Australia & 22 & 0 & \\
\hline Africa & & 1 & 0 & \\
\hline \multirow[t]{2}{*}{ Africa } & Egypt & 1 & 0 & \\
\hline & Total & 78833 & 2463 & \\
\hline
\end{tabular}


Table 3: As of 23 February 2020, distribution of laboratory confirmed cases of COVID-19 in the EU/EEA and the UK ${ }^{20}$

\begin{tabular}{|l|l|l|l|}
\hline EU/EEA and the UK & Imported cases & Locally acquired cases & Total \\
\hline Italy & 3 & 76 & 79 \\
\hline Germany & 2 & 14 & 16 \\
\hline France & 5 & 7 & 12 \\
\hline United Kingdom & 8 & 1 & 9 \\
\hline Spain & 2 & & 2 \\
\hline Sweden & 1 & & 1 \\
\hline Finland & 1 & & 1 \\
\hline Belgium & 1 & & 1 \\
\hline Total & 23 & 98 & 121 \\
\hline
\end{tabular}

Until now, the majority of cases are from China, especially Hubei province. Sporadic but increasing cases have also been reported in other countries globally mainly among travelers from China. In the following days, updated case counts can be found on the WHO and ECDC websites.

\section{CLINICAL FEATURES}

The incubation period of 2019-nCoV is thought to be within 14 days following exposure. Pneumonia appears to be the most serious manifestation of infection, characterized primarily by fever, cough, dyspnea, and bilateral infiltrates on chest imaging. However, patients can present with a spectrum of disease ranging from mild respiratory illnesses including a runny nose, sore throat, cough, and fever to severe disease requiring intensive care. Mild disease is common in healthy younger adults or children. Although we still need to learn more about how the new virus influences human, so far, older people, and people with comorbid medical conditions (such as diabetes and heart disease) seem to be more at risk of forming severe disease 15. Asymptomatic infection is possible but the frequency of asymptomatic infection is unknown. However approximately 20 percent of confirmed patients have had critical illness. The overall case fatality rate is uncertain, because, the outbreak is in progress. With current numbers, the fatality rate for COVID-19 is approximately $3.1 \%$.

In a study including 62 patients with laboratoryconfirmed 2019-nCoV, fever (77\%) and cough ( $81 \%$ ) have been found as the most common symptom. In mentioned study, on admission, bilateral involvement on chest radiographs in $84 \%$, leucopenia in $31 \%$ and lymphopenia in $42 \%$ of the patients were found. Characteristic chest computed tomography findings of infected patients on admission were bilateral or multiple lobular or subsegmental areas of consolidation or bilateral ground glass opacity ${ }^{23}$.

While the outbreak continue, human-to-human transmission confirmed in different countries ${ }^{15}$. Reproduction number is an indication of the transmissibility of a virus, representing the average number of new infections generated by an infectious person in a totally naive population. Liu et al,. found that the average reproduction number for 2019-nCoV to be 3.28. The authors stated that the reproduction number of $2019-\mathrm{nCoV}$ is higher compared to SARS coronavirus ${ }^{24}$. This data indicate the potential of new coronavirus (2019$\mathrm{nCoV}$ ) to cause outbreaks.

\section{DIAGNOSIS}

Currently, all clinicians should be consider the possibility of COVID-19 in patients with fever and/or lower respiratory tract symptoms who reside in or have recently (within the prior 14 days) traveled to China or who have had recent (within the prior 14 days) close contact with a confirmed or suspected case of 2019-nCoV. This is important for early recognition of suspect cases and taking infection control measures.

The specific case definitions and clinical criteria for diagnostic evaluation differ slightly between expert groups. Here, the case definitions of 2019 nCov of WHO is given ${ }^{25}$.

According to WHO, case definitions for surveillance is follow:

\section{Suspect case:}

A. Patient with severe acute respiratory infection (fever, cough, and requiring admission to hospital), AND with no other etiology that fully explains the clinical presentation AND a history of travel to or residence in China during the 14 days prior to symptom onset, 
OR

B. Patient with any acute respiratory illness AND at least one of the following during the 14 days prior to symptom onset:

a) contact with a confirmed or probable case of 2019-nCoV infection, or

b) employed in or attended a health care facility where patients with confirmed or probable 2019$\mathrm{nCoV}$ acute respiratory disease patients were being treated.

Confirmed case is a person with laboratory confirmation of 2019-nCoV infection, regardless of clinical signs and symptoms.

At present, due to COVID-19 have also seen in some countries outside China, if a person with severe acute respiratory infection had a history of visiting to areas with assumed continuing community transmission, the clinicians should be keep in mind this disease. Any person meeting the criteria for a suspected case should be tested for SARS-CoV-2. SARS-CoV-2 can be detected by polymerase chain reaction in a reference laboratory.

WHO has made a lot of tests available to WHO Regional offices and national laboratories. These tests are being shipped to some laboratories across all WHO regions. Also, CDC has developed a real time Reverse Transcription-Polymerase Chain Reaction (rRT-PCR) test that can diagnose 2019$\mathrm{nCoV}$ in respiratory samples from clinical specimens ${ }^{26}$.

For definitive diagnosis, when possible, specimens from both lower (i.e. bronchoalveolar lavage, endotracheal aspirate, or expectorated sputum) and upper respiratory tracts (i.e. nasopharyngeal swab, oropharyngeal swab, nasopharyngeal aspirate or nasal wash) should be collected ${ }^{27}$. Induction of sputum is not indicated. Routinely, viral culture is not recommended due to safety ${ }^{28}$. Respiratory sample collection from the upper and especially lower respiratory tract, should be applied under maximum infection prevention and control measures including airborne precautions ${ }^{27}$.

TREATMENT: COVID-19 is caused by the virus SARS-CoV-2. Although several antiviral drugs have been tried, at present, there is no specific antiviral treatment for $2019-\mathrm{nCoV}$ pneumonia. Supportive care is the main treatment for COVID19.

Routine corticosteroids should be avoided in 2019$\mathrm{nCoV}$ pneumonia unless they are indicated for another reason. Arabi et al., showed that corticosteroid therapy in patients with MERS was associated with delayed MERS coronavirus RNA clearance ${ }^{29}$.

There was some report suggesting Lopinavir /Ritonavir or Remdesivir could be the drug treatment options for 2019-nCoV. Remdesivir is an adenosine analogue. It incorporates into nascent viral RNA chains and results in pre-mature termination. Remdesivir has been lately recognized as a hopeful antiviral drug against for some RNA viruses like SARS and MERS-CoV infection in cultured cells, mice and nonhuman primate models. It is also at present under clinical development for the treatment of Ebola virus infection. Wang et al. reported that remdesivir and chloroquine are extremely effective in the control of $2019-\mathrm{nCoV}$ infection in vitro. The authors has suggested that remdesivir and chloroquine can be beneficial for COVID- $19^{30}$. Li et al. reported that some antiviral drugs such as remdesivir, lopinavir/ritonavir or lopinavir/ritonavir combined with interferon- $\beta$ can be effective for 2019-nCoV ${ }^{31}$. Sheahan et al. reported that remdesivir is a potential drug o treat MERS-CoV infections. They found that remdesivir and interferon beta have superior antiviral activity to lopinavir and ritonavir in vitro ${ }^{32}$.

Although there are some studies, the efficacy and safety of these drugs for 2019- nCoV still need to be further confirmed by clinical experiments.

\section{PREVENTION}

There is no approved vaccine for COVID-19 yet. Therefore prevention of the disease is very important in community settings and in the healthcare settings. Individuals with suspected infection in the community have to wear a medical mask and as soon as possible apply to a medical centre. The optimal way to avoid infection from having potentially touched a contaminated surface is still to avoid touching your face with your hands, and to wash your hands with soap and water often.

HCWs who follow COVID-19 patients are at risk. In the hospital settings, when COVID-19 is suspected, infection control measures should be implemented and public health officials notified.

WHO published a guidance on infection prevention and control (IPC) strategies for use when infection with a novel coronavirus (2019-nCoV) is suspected 33. WHO stated that these recommendations will update as new information becomes available. According to the this guide, isolating patients with suspected nCoV infection, applying standard precautions for all patients, implementing additional precautions including droplet and contact and, whenever applicable, airborne 
precautions for suspected cases of $\mathrm{nCoV}$ infection are very important to infection prevention and control.

Standard precautions include hand and respiratory hygiene, the use of appropriate personal protective equipment (PPE) according to risk assessment, injection safety practices, safe waste management, proper linens, environmental cleaning and sterilization of patient-care equipment.

HCWs in contact with COVID-19 patients should use appropriate personal protective equipment like eye protection, face shield, a medical mask, a longsleeved gown, gloves.

As a respiratory hygiene;

- All patients have to cover their nose and mouth with a tissue or elbow when coughing or sneezing,

- Everyone have to perform proper hand hygiene after contact with respiratory secretions.

-The patients with suspected 2019-nCoV are recommended to wear medical mask while waiting in public areas or in cohorting rooms.

HCWs should supply proper hand hygiene before touching a patient, before any clean or aseptic procedure is performed, after exposure to body fluid, after touching a patient, and after touching a patient's surroundings. Hand hygiene can supply by alcohol-based hand rubs are preferred if hands are not visibly soiled, otherwise, it should be washed with soap and water when they are visibly soiled.

It should be routinely cleaned and disinfect surfaces which the patient is in contact. Generally, fully cleaning environmental surfaces with water and detergent and applying commonly used hospital-level disinfectants for example sodium hypochlorite are efficient and adequate procedures.

Everyone should apply contact and droplet precautions before entering the room where suspected or confirmed nCoV patients are admitted. The patients should be placed in sufficiently ventilated single rooms. When single room is not available, the patient should be assigned to the cohort room. One meter or more space have to maintain between the beds in a cohort isolation room. The doors to the isolation rooms should be closed, and there should be sufficient external ventilation. HCWs should use a medical mask.

Tracheal intubation, bronchial suctioning, noninvasive ventilation, tracheotomy, cardiopulmonary resuscitation, sputum induction, manual ventilation before intubation, and bronchoscopy are aerosol-generating procedures. These procedures have been related with an increased risk of transmission of coronaviruses like SARS-CoV and MERS-CoV. So, in this case, airborne precautions should be taken. HCWs performing aerosol-generating procedures should use a particulate respirator as a US National Institute for Occupational Safety and Health (NIOSH)-certified N95, European Union (EU) standard FFP2, or the other equivalent.

The medical equipment should be either single-use and disposable or devoted equipment. If equipment needs to be shared among patients, it should clean and disinfect it between use for each individual patient (e.g., by using ethyl alcohol 70\%).

The patients should stay their room unless medically necessary. If transport is required, it should be use predetermined transport routes to minimize exposure for other people.

All samples collected for laboratory studies should be accepted as potentially infectious. Specimens for transport should place in leak-proof specimen bags (i.e., secondary containers) that have a separate sealable pocket for the specimen (i.e., a plastic biohazard specimen bag). It should not to use use pneumatic-tube systems to transport specimens.

ECDC announced that although there is so far no evidence of airborne transmission, they recommend a cautious approach due to lack of studies excluding this mode of transmission ${ }^{34}$.

Staff providing care to confirmed 2019-nCoV cases, and staff who have been exposed to cases before the implementation of infection control measures, should be awake in terms of fever and any respiratory symptoms in the 14 days following the last exposure to a confirmed case.

The duration of infectivity for 2019-nCoV patients remains unknown. However patients with severe ill can spread 2019-nCoV for long times. Confirmed 2019-nCoV cases should remain in isolation until recovery from clinical symptoms of 2019-nCoV and viral detection tests should assist in the decision on when to discontinue additional precautions for hospitalised patients.

In conclusion, the outbreak of $2019-\mathrm{nCoV}$ has become an important problem of today. Unfortunately, the outbreak is in progress worldwide. It is hard to say how many people will be effected by it in the future. The situation with the new coronavirus is rapidly changing, so, the new information about 2019-nCoV are continue. That's why, it should be kept in mind that 
definitions, diagnostic tools or treatment options may change in the upcoming days. Updated

\section{REFERENCES}

1. World Health Organization. Novel coronavirus (2019-nCoV) situation report-1. 21 January $2020 . \quad \mathrm{https} / / / \mathrm{www}$.who.int/docs/defaultsource/coronaviruse/situationreports/20200121-sitrep-1-2019ncov.pdf?sfvrsn=20a99c10_4 (Accessed on February 15, 2020).

2. bioRxiv.org (homepage on the Internet) (The preprint server for biology). Available from: https://www.biorxiv.org/content/10.1101/2020. 01.30.927871v2 (Accessed on February 16, 2020).

3. www.uptodate.com. Kenneth McIntosh (author). Coronaviruses. (Accessed on February 24, 2020). Available from: https://www.uptodate.com/contents/coronaviru ses? search $=$ novel $\% 20$ coronavirus\&source $=$ sea rch_result\&selectedTitle $=3 \sim 19 \&$ usage_type $=d$ efault\&display_rank=3

4. The Turkish Ministry of Health, General Directorate of Public Health. 2019-nCoV Disease, Healthcare Professionals Guide. January 2020. (In Turkish: T. C. Sağlık Bakanlığı Halk Sağlığı Genel Müdürlüğü. 2019-nCoV Hastalığı Sağlık Çalışanları Rehberi, Ocak 2020). https://hsgm.saglik.gov.tr/depo/haberler/ncov/2 019-nCov_Hastal_Salk_alanlar_Rehberi.pdf

5. Liu P, Chen W, Chen JP. Viral Metagenomics Revealed Sendai Virus and Coronavirus Infection of Malayan Pangolins (Manis javanica). Viruses 2019;11(11).

6. Paules CI, Marston HD, Fauci AS. Coronavirus Infections-More Than Just the Common Cold. JAMA 2020 Jan 23. doi: 10.1001/jama.2020.0757. [Epub ahead of print].

7. Lu R, Zhao $\mathrm{X}$, Li J, et al. Genomic characterisation and epidemiology of 2019 novel coronavirus: implications for virus origins and receptor binding. Lancet 2020 Jan 30. doi: 10.1016/S0140-6736(20)30251-8. [Epub ahead of print].

8. Wan Y, Shang J, Graham R, Baric RS, Li F. Receptor recognition by novel coronavirus from Wuhan: An analysis based on decade-long structural studies of SARS. J Virol 2020 Jan 29. information about 2019-nCoV and COVID 2019 can be found WHO, CDC and ECDC websites.

doi: 10.1128/JVI.00127-20. [Epub ahead of print].

9. www. nature.com. Did pangolins spread the China coronavirus to people? Available from: https://www.nature.com/articles/d41586-02000364-2 (Accessed February 22, 2020).

10. World Health Organization. Summary of probable SARS cases with onset of illness from 1 November 2002 to 31 July 2003. Available from:

https://www.who.int/csr/sars/country/table200 4_04_21/en/ (Accessed February 14, 2020).

11. www.uptodate.com. Kenneth McIntosh (author). Severe acute respiratory syndrome (SARS). (Accessed on February 24, 2020). Available from: https://www.uptodate.com/contents/severeacute-respiratory-syndromesars? search=Severe\%20acute\%20respiratory\% 20syndrome\&source=search_result\&selectedT itle $=1 \sim 150 \&$ usage_type $=$ default \&display_rank $=1$

12. World Health Organization. MERS Global Summary and Assessment of Risk. July 2019. Available from: https://apps.who.int/iris/bitstream/handle/1066 5/326126/WHO-MERS-RA-19.1eng.pdf?ua $=1$ (Accessed February 22, 2020).

13. Li Q, Guan X, Wu P, et al. Early Transmission Dynamics in Wuhan, China, of Novel Coronavirus-Infected Pneumonia. N Engl J Med 2020 Jan 29. doi: 10.1056/NEJMoa2001316. [Epub ahead of print].

14. Centers for Disease Control and Prevention. How COVID-19 Spreads. https://www.cdc.gov/coronavirus/2019ncov/about/transmission.html (Accessed February 18, 2020).

15. World Health Organization .Q\&A on coronaviruses. https://www.who.int/news$\mathrm{room} / \mathrm{q}$-a-detail/q-a-coronaviruses (Accessed February 18, 2020).

16. World Health Organization. Novel coronavirus (2019-nCoV) situation report-11. 31 January 2020. https://www.who.int/docs/defaultsource/coronaviruse/situationreports/20200131-sitrep-11- 
ncov.pdf?sfvrsn=de7c0f7_4 (Accessed on February 22, 2020).

17. World Health Organization. Coronavirus disease (COVID-2019) situation reports. https://www.who.int/emergencies/diseases/nov el-coronavirus-2019/situation-reports/

(Accessed February 22, 2020).

18. World Health Organization. Novel coronavirus (2019-nCoV) situation report-34 23 February $2020 . \quad \mathrm{https}: / /$ www.who.int/docs/defaultsource/coronaviruse/situation-

reports/20200223-sitrep-34-covid-

19.pdf?sfvrsn=44ff8fd3_2 (Accessed on February 24, 2020).

19. European Centre for Disease Prevention and Control. Geographic distribution of COVID-19. Available from: https://www.ecdc.europa.eu/en/geographicaldistribution-2019-ncov-cases (Accessed on February 24, 2020).

20. European Centre for Disease Prevention and Control. Situation update for the EU/EEA and the UK. https://www.ecdc.europa.eu/en/cases2019-ncov-eueea (Accessed on February 24, 2020).

21. World Health Organization. Coronavirus disease 2019 (COVID-19) Situation Report-25. https://www.who.int/docs/default-

source/coronaviruse/situation-

reports/20200214-sitrep-25-covid-

19.pdf?sfvrsn=61dda7d_2 (Accessed on January 23, 2020).

22. Wikipedia. Li Wenliang. Available from: https://en.wikipedia.org/wiki/Li_Wenliang (Accessed on January 23, 2020).

23. Xu XW, Wu XX, Jiang XG, et al. Clinical findings in a group of patients infected with the 2019 novel coronavirus (SARS-Cov-2) outside of Wuhan, China: retrospective case series. BMJ 2020 Feb 19; doi: 10.1136/bmj.m606.

24. Liu Y, Gayle AA, Wilder-Smith A, Rocklöv J. The reproductive number of COVID-19 is higher compared to SARS coronavirus. J Travel Med 2020 Feb 13. doi: 10.1093/jtm/taaa021. [Epub ahead of print].

25. World Health Organization. Novel Coronavirus (2019-nCoV) technical guidance: Surveillance and case definitions. Global Surveillance for human infection with novel coronavirus (2019nCoV), Interim guidance, 31 January 2020. https://www.who.int/publicationsdetail/global-surveillance-for-human-infection- with-novel-coronavirus-(2019-ncov) (Accessed on February 20, 2020).

26. Centers for Disease Control and Prevention. CDC Tests for COVID-19. https://www.cdc.gov/coronavirus/2019ncov/about/testing.html (Accessed on February 20, 2020).

27. European Centre for Disease Prevention and Control. Case definition and European surveillance for human infection with novel coronavirus (SARS-CoV-2). https://www.ecdc.europa.eu/en/case-definitionand-european-surveillance-human-infectionnovel-coronavirus-2019-ncov (Accessed on February 20, 2020).

28. www.uptodate.com. Kenneth McIntosh (author). Coronavirus disease 2019 (COVID19). Available from: https://www.uptodate.com/contents/coronaviru s-disease-2019-covid-

19 ? search $=$ novel $\% 20$ coronavirus\&source $=$ sear ch_result\&selectedTitle $=1 \sim 19 \&$ usage_type $=$ de fault\&display_rank=1 (Accessed on February 24, 2020).

29. Arabi YM, Mandourah Y, Al-Hameed F, et al. Corticosteroid Therapy for Critically Ill Patients with Middle East Respiratory Syndrome. Am J Respir Crit Care Med 2018;197(6):757-767.

30. Wang M, Cao R, Zhang L, et al. Remdesivir and chloroquine effectively inhibit the recently emerged novel coronavirus (2019-nCoV) in vitro. Cell Res 2020 Feb 4. doi: 10.1038/s41422-020-0282-0.

31. Li H, Wang YM, Xu JY, Cao B. Potential antiviral therapeutics for 2019 Novel Coronavirus. Zhonghua Jie $\mathrm{He} \mathrm{He} \mathrm{Hu} \mathrm{Xi} \mathrm{Za}$ Zhi. 2020 Feb 5; doi: 10.3760/cma.j.issn.10010939.2020.0002. [Epub ahead of print] Chinese.

32. Sheahan TP, Sims AC, Leist SR, et al. Comparative therapeutic efficacy of remdesivir and combination lopinavir, ritonavir, and interferon beta against MERS-CoV. Nat Commun 2020 Jan 10;11(1):222.

33. World Health Organization. Infection prevention and control during health care when novel coronavirus (nCoV) infection is suspected. Interim guidance, 25 January 2020. https://www.who.int/publicationsdetail/infection-prevention-and-control-duringhealth-care-when-novel-coronavirus-(ncov)infection-is-suspected-20200125 (Accessed on January 23, 2020). 
34. European Centre for Disease Prevention and Control. ECDC Technical Report, Infection prevention and control for the care of patients with 2019-nCoV in healthcare settings. February 2020. Available from: https://www.ecdc.europa.eu/sites/default/files/ documents/nove-coronavirus-infectionprevention-control-patients-healthcaresettings.pdf (Accessed on February 20, 2020). 